\title{
Effects of energy conservation in major energy-intensive industrial sectors on emissions of polychlorinated dibenzo-p-dioxins and polychlorinated dibenzofurans in China
}

\author{
Jing Geng a,b,c, Yonglong Lu ${ }^{\mathrm{a}, *}$, Tieyu Wang ${ }^{\mathrm{a}}$, John P. Giesy ${ }^{\mathrm{d}, \mathrm{e}}$, Chunli Chen ${ }^{\mathrm{a}}$ \\ a State Key Laboratory of Urban and Regional Ecology, Research Center for Eco-Environmental Sciences, Chinese Academy of Sciences, Beijing 100085, China \\ ${ }^{\mathrm{b}}$ Business Administration College, Taiyuan University of Technology, Taiyuan, Shanxi 030024, China \\ ${ }^{c}$ Graduate School of Chinese Academy of Sciences, Beijing 100039, China \\ ${ }^{\mathrm{d}}$ Department of Veterinary Biomedical Sciences and Toxicology Centre, University of Saskatchewan, 44 Campus Drive, Saskatoon, SK, Canada \\ e Department of Zoology, Center for Integrative Toxicology, Michigan State University, E. Lansing, MI, USA
}

\section{A R T I C L E I N F O}

\section{Article history:}

Received 23 September 2009

Accepted 10 December 2009

Available online 6 January 2010

Keywords:

Polychlorinated dibenzo- $p$-dioxins

Polychlorinated dibenzofurans

Energy efficiency

\begin{abstract}
A B S T R A C T
China has set an ambitious target of increasing energy efficiency by $20 \%$ and reducing pollution discharges by $10 \%$ over the period 2006-2010. Promoting advanced technologies and closing outdated facilities are widely recognized as important measures to achieve these targets. These actions can also indirectly decrease release of polychlorinated dibenzo-p-dioxins (PCDDs) and polychlorinated dibenzofurans (PCDFs). The objectives of this paper are to identify and quantify reductions of PCDD/F emissions to air due to measures such as phasing out of obsolete facilities in the four most energyintensive industrial sectors. Reductions in PCDD/F emissions from power generation were estimated to be 7, 33 and $38 \mathrm{~g}$ I-TEQ in 2006, 2007 and 2008, respectively. For the cement industry, reductions were estimated to be $680 \mathrm{~g}$ I-TEQ between 2007 and 2008, and $740 \mathrm{~g}$ I-TEQ between 2009 and 2010. For the iron and steel industry, the reduction was estimated to be $113.3 \mathrm{~g}$ I-TEQ over the period 2007-2010, which includes $76.6 \mathrm{~g}$ I-TEQ in 2007. For the coke industry, the reduction was estimated to be $68 \mathrm{~g}$ I-TEQ in 2007 and $62 \mathrm{~g}$ I-TEQ in 2008
\end{abstract}

(c) 2009 Elsevier Ltd. All rights reserved.

\section{Introduction}

After they were originally detected in flue gases and in the fly ash of municipal solid waste incinerators (Olie et al., 1977), polychlorinated dibenzo-p-dioxins (PCDDs) and polychlorinated dibenzofurans (PCDFs) have been extensively studied because of their potential adverse health effects (McKay, 2002; Tuppurainen et al., 1998).

In developed countries, release of PCDD/Fs from industry and municipal solid waste incinerations have historically been among most significant sources of PCDD/Fs, but due to stringent limits placed upon them, emissions from these sources have been greatly reduced. In the USA, emissions of PCDD/Fs from municipal waste combustion have been reduced approximately 99\% from 8905.1 g 2,3,7,8-tetrachlorodibenzo-p-dioxin (TCDD) Equivalents (WHO-TEQ) in 1987 to $83.8 \mathrm{~g}$ WHO-TEQ in 2000 (USEPA, 2006). In the United Kingdom, emissions of I-TEQ from incinerators were estimated to be $409 \mathrm{~g}$ in 1993 and $0.54 \mathrm{~g}$ in 2004 . The latter accounted for less than $0.5 \%$ of the total I-TEQ emissions in the UK

\footnotetext{
* Corresponding author. Tel.: +8610 62849466; fax: +86 1062918177

E-mail addresses: yllu@rcees.ac.cn, yllu@cashq.ac.cn (Y. Lu).
}

(UK DEFRA, 2007). It has been estimated that total emissions of I-TEQ to the air of Japan were decreased by 95\% between 1997 and 2004 (Japan MOE, 2005).

In China, regulations for control of dioxins from the waste incineration industry went into effect in 2002 (GB18484-2001, GB18485-2001). In addition, technical specifications for centralized incineration of medical, hazardous chemical and municipal solid wastes (HJ/T 177-2005, HJ/T 176-2005, CJJ90-2009) have been issued that have resulted in reductions in admissions for these sources. Until now waste incineration had been identified as a major source of PCDD/F emissions in China and much attention has been paid to reduce emissions of I-TEQ from these sources. Currently, at some large-scale municipal solid waste incinerators emissions of PCDD/Fs are less than the national standard limit of $1.0 \mathrm{ng}$ TEQ $\mathrm{Nm}^{-3}$, and even European Union Directive value of $0.1 \mathrm{ng}$ TEQ $\mathrm{Nm}^{-3}$ (Bie et al., 2007; Ni et al., 2009; Nie, 2008; Yan et al., 2006).

While much progress has been made in controlling emissions from waste incineration, release of PCDD/Fs from energyintensive industries, such as the metallurgical, heat and power generation and chemical production industries have not been regulated in China. Also, other industrial processes, such as iron sintering, secondary metallurgical melting, pulp and paper 
production using chlorine have been identified as major emission sources of PCDD/Fs (Quaß et al., 2004; UNEP Chemicals (2006); Zheng et al., 2001). In addition, lesser concentrations of PCDD/Fs have been measured in flue gases from coke production, coal-fired power plants and cement production (Bremmer et al., 1994; Fernández-Martínez et al., 2004; Lin et al., 2007; Karstensen, 2006b). While concentrations of PCDD/Fs from these sources are less, because of the relatively great volume of gas flow emission and different operating conditions they cannot be neglected. It has been estimated that in 2004 emissions of PCDD/Fs from the metallurgical industry accounted for $45.6 \%$ of emissions of PCDD/ Fs in China. The next greatest source was determined to be power and heat generation, which accounted for $18.5 \%$ of the total (China, 2007). Therefore, the emissions from these energyintensive industries can contribute significantly to the overall release of PCDD/DF.

The output of energy-intensive industries in China rose sharply between 2002 and 2005. During that time China became the world's largest producer of iron and steel, cement, coke, flat glass and aluminum. The rapid development of these industrial sectors resulted in a significant increase in energy demand and energyrelated pollutant emissions. The sustained decline in energy intensity in the period 1980-2001 was reversed in 2002 (Andrews-Speed, 2009). In this period, approximately $84 \%$ of the increased industrial energy consumption resulted from seven industrial sectors, with the iron and steel sector accounting for 30.3\% (Liao et al., 2007).

China's energy-related $\mathrm{CO}_{2}$ emissions, which were $60 \%$ of those of the United States in 2002, approached the US level by 2005 and surpassed it in 2006. The rate of increase in $\mathrm{CO}_{2}$ is much faster than expected (Levine and Aden, 2008; Levine et al., 2009).

In the 11th Five-Year Plan for National Economic and Social Development (2006-2010), the government set a target of reducing energy consumption per unit GDP by $20 \%$ relative to that of 2005 by 2010. In addition, total amount emissions of major pollutants discharged is to be reduced by $10 \%$ over the same period of time.

Because of the failure to reach the energy saving and discharge reduction goals set for 2006, the State Council published a General Work Plan for Energy Conversation and Pollution Discharge Reduction in 2007 (State Council of the People's Republic of China, 2007a). Since a disproportionately large number of smallscale plants, which are both inefficient users of energy and also were relatively larger emitters still existed in China's energyintensive industries, the Plan set a list of targets to accelerate elimination of small-sized but high emission producers in 13 industrial sectors. Subsequently the National Development and Reform Commission (NDRC) and the Ministry of Industry and Information Technology (MIIT) released enterprise lists with the deadline for closure and related capacities in several major energy-intensive industries. The facilities and production lines listed for the closure would be dismantled and the sites would be cleared and redeveloped. This plan not only improved energy use efficiency, but also reduced emissions of $\mathrm{SO}_{2}, \mathrm{NO}_{x}$ and chemical oxygen demand. This is being achieved through a combination of elimination of small-capacity facilities and upgrading of industrial facilities. These changes can also make a contribution to the reduction of $\mathrm{PCDD} / \mathrm{F}$ emissions. In China's National Implementation Plan (NIP) for the Stockholm Convention on Persistent Organic Pollutants (POPs), the measures of industrial structural adjustment, such as encouraging advanced technologies and eliminating old, small-scale and inefficient capacities have been identified that have an impact indirectly on the reduction of release of dioxins (China, 2007; Lu and Giesy, 2005).

However, there was no quantitative estimate of the effects of these measures. Therefore, the aim of this paper was to examine how energy conservation and pollution discharge reduction would impact the reduction amounts of PCDD/Fs to air in China. The study investigated four energy-intensive industrial sectors including the power production, cement, iron and steel production and coke production sectors, all of which were major PCDD/F emission sources in China. This was done by estimating reductions in PCDD/F emissions due to closure of outdated production capacities. For each industrial sector, the assessment began with an industrial overview including its growth, energy consumption and environmental significance. It then examined key policies for promoting industrial energy efficiency and pollution discharge reduction including eliminating small-scale facilities and developing new technologies over the period of the 11th Five-Year Plan (from 2006 to 2010). The investigation then examined the effects of closing outdated facilities. Third, the reported concentrations or emissions of $\mathrm{PCDD} / \mathrm{Fs}$, selected the appropriate emission factors for estimation and estimated reductions of PCDD/Fs to air was reviewed. The estimated reductions in emissions of PCDD/Fs will assist governments to know the effects of regulatory actions to date and make effective proposals for future actions in energyintensive industries.

\section{Power industry}

\subsection{Recent developments, energy consumption and pollutant emissions in China's power industry}

Between 2000 and 2007, the average annual growth rate of electricity consumption in China was 13.5\% (NBSC, 2001-2008). In 2007, electricity consumption reached 3271 billion kWh. The installed generating capacity was $718 \mathrm{GW}$, of which, thermal power generation capacity accounted for $77 \%$ (China Electricity Yearbook Editorial Board, 2007-2008). In China, coal-fired generation capacity was responsible for $95 \%$ of the thermal capacity, which is one of the greatest proportions in the world, although less than Australia, South Africa and Poland (IEA, 2007).

While the power industry provides energy to other sectors, it is the largest coal consumer. Coal consumption for electricity supply was 1.3 billion tons in 2007 , which accounted for $55 \%$ of China's coal consumption (NBSC, 2001-2008). Rapid expansion of electricity consumption and its primary reliance on coal have had a profound environmental impact. China's coal-power plants were responsible for approximately $53 \%$ of the national $\mathrm{SO}_{2}$ emissions, $36 \%$ of $\mathrm{NO}_{x}$ emissions and less than $10 \%$ of $\mathrm{PM}$ emissions in 2005 (Zhao et al., 2008). Thus, the government has strategically identified the power industry as one of the priority sectors that are targeted to improve energy efficiency and to reduce emissions.

\subsection{Promote larger units and limit small units}

Higher power efficiencies would mean that power plants would burn less coal to generate the same number of kWh, which in turn would produce less overall air pollution. To achieve this target, the government has undertaken building larger power generating units and shutting down small thermal units to optimize the power structure for the thermal power sectors. Different capacity generation units have different energy efficiencies. The annual average coal consumption per unit electricity-supply for units smaller than 100, 100-200, 200-300, 300-600 MW, and larger than $600 \mathrm{MW}$ were 440, 379, 365, 335 and 326 gce $\mathrm{kWh}^{-1}$, respectively (Zhao et al., 2008). Considering the lesser consumption for large units, the government has mandated that all new thermal generation units must be at least 
$600 \mathrm{MW}$ and use at least supercritical generation technology. Moreover, a number of other advanced power generation technologies including ultra-supercritical generation technology, circulating fluidized bed combustion generation technology and integrated gasification combined-cycle generation technology have been developed to improve thermal efficiency and to reduce pollutant emissions (SERC, 2008a).

Efforts to control small and inefficient units in China began as early as the Ninth Five-Year Period (1996-2000), in which the small thermal power plants with a total installed capacity of $9640 \mathrm{MW}$ were closed, but the efforts slowed during the Tenth Five-Year Period (2001-2005) (Fang et al., 2006). The main reason for this was that from 2002 China's economic growth has constantly outstripped the nation's ability to increase power production. Worsening power shortages encouraged construction of many small thermal power plants, which required less investment but yielded instant returns. This irrational investment reached a maximum in 2005.

From 2006, a series of actions have been taken to reverse this situation again. First, NDRC published a notice that called for a comprehensive check on the closure of smaller thermal power plants and made public a list of all plants slated to be closed through 2010 (NDRC, 2006c). Later, the State Council endorsed a plan to accelerate closure of the small thermal power plants. NDRC and the State Energy Administration set concrete targets and measures for decommissioning small units. The small units include all coal-fired power plants that meet the following criteria: a capacity of $50 \mathrm{MW}$ or less; over 20 years units of $100 \mathrm{MW}$ or less; units of $200 \mathrm{MW}$ or less that are older than their designed life expectancy; all units with coal consumption of $10 \%$ or greater than the provincial average, or $15 \%$ greater than the national average; all units cannot meet the emission standards. Moreover, to accelerate the retirement of small units, the government built a close linkage between retiring of inefficient small units and building of efficient large units. To build new power units with capacities of 300,600 or $1000 \mathrm{MW}$ smaller units corresponding $80 \%, 70 \%$ or $60 \%$ of the capacity must first be closed (State Council of the People's Republic of China, 2007b).

These recent strategies have proven effective. The number of smaller units closed between 2006 and 2008 are given (see Table 1) (NDRC et al., 2009; SERC, 2008b). The smaller units that have been closed had a total installed capacity of 34,210 MW. Thus, these actions have achieved $68 \%$ of the target set in the 11 th Five-Year Plan. In 2007, the smaller units (less than $100 \mathrm{MW}$ ) represented $18.8 \%$ of the total capacity, compared with $30.9 \%$ and $23.6 \%$ in 2005 and 2006, respectively (SERC, 2008c). With the retirement of smaller units and the development of larger units, the average coal consumption per unit electricity supply was 357 gce $\mathrm{kWh}^{-1}$ in 2007, which represented an increase in efficiency of approximately 10 gce $\mathrm{kWh}^{-1}$ compared to the previous year (China Electricity Yearbook Editorial Board, 20072008). This is the largest increase in efficiency on record. Through the integrated measures taken for energy conservation, the power industry saved energy which was equivalent to 64.92 million tons

Table 1

Number of small power units closed in China between 2006 and 2008. (Source: NDRC et al., 2009; SERC, 2008b; adapted and calculated the total capacities by the authors).

\begin{tabular}{lccc}
\hline Year & $\begin{array}{l}\text { Number of } \\
\text { companies }\end{array}$ & $\begin{array}{l}\text { Number } \\
\text { of units }\end{array}$ & $\begin{array}{l}\text { Installed } \\
\text { capacity } \\
\text { (MW) }\end{array}$ \\
\hline 2006 & 48 & 317 & 3140 \\
2007 & 171 & 553 & 14,380 \\
2008 & 325 & 3269 & 16,690 \\
\hline
\end{tabular}

of standard coal, reduced $\mathrm{SO}_{2}$ emissions by about 1.03 million tons (about $7.65 \%$ of $\mathrm{SO}_{2}$ emissions by power industry in 2006) and $\mathrm{CO}_{2}$ emissions for about 180 million tons in 2007 (SERC, 2008c). Environmental protection devices, especially flue gas desulfurization systems, have also been deployed rapidly in coal power plants since 2006. The total installed coal power plants capacity with $\mathrm{SO}_{2}$ scrubbers was near seven-fold greater than that in 2005 (Xu et al., 2009).

Although the data on closing in 2009 cannot be reported completely, the deputy director of the National Energy Administration (NEA) claimed at a news conference that as of June 30, 2009, China has closed down 7467 small thermal units with a total capacity of $54,070 \mathrm{MW}$. The target of closure in the 11th Five-Year Plan has been achieved one and a half year ahead of schedule. According to the NEA, the closure of 54,070 MW units can reduce $\mathrm{SO}_{2}$ emissions by 1.06 million tons and reduce $\mathrm{CO}_{2}$ emissions by 124 million tons each year (NEA, 2009).

\subsection{Reduction of $P C D D / F$ emissions to air in the power industry}

The emission factor to air for two coal-fired power units equipped with an ESP and a wet scrubber with a net electric potential of $2 \times 518 \mathrm{MW}$ has been estimated to be $0.35 \mu \mathrm{g}$ I-TEQ per ton coal burned. The emission factor for a chain grate stoker equipped with a cyclone APCD was $1.6 \mu \mathrm{g}$ I-TEQ per ton coal burned (Bremmer et al. 1994). The emission factor for release of PCDD/Fs to air was found to be 0.133 and $1.11 \mu \mathrm{g}$ I-TEQ per ton coal burned for two coal-fired power plants (Lin et al. 2007). The mean emission factor $0.62 \mu \mathrm{g}$ I-TEQ per ton coal burned was used to estimate the dioxin emission inventory in Taiwan. Since different types of coal are used and power generating facilities are equipped with different air pollution control devices, the emission factors vary among power plants and thus different values are used by different countries and regions. Emission factors of 0.079 (USEPA, 2006), $0.03-0.2$ and $0.06-0.32 \mu \mathrm{g} \mathrm{I}$ TEQ ton $^{-1}$ (Quass et al., 2000) have been used to estimate annual emissions of I-TEQ to air from coal-fired power plants by USA, Germany and UK, respectively. For the UNEP PCDD/Fs Toolkit

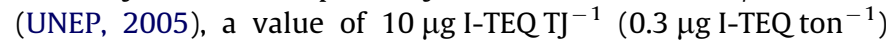
was chosen. Furthermore, if no inventory information is available, the European Union (EU) recommended a range of emission factors from 0.1 to $0.4 \mu \mathrm{g}$ I-TEQ ton ${ }^{-1}$ for power plants (fossil fuels) and $0.5-1.5 \mu \mathrm{g} \mathrm{I-TEQ} \mathrm{ton}{ }^{-1}$ for small and medium-size industrial combustion facilities (fossil fuels) (Quass et al., 2000).

Since there is generally better control of releases by power plants in more developed countries than there currently is in China (Graus and Worrell 2007) and the data available is mostly from more modern large-scale power plants, emission factors of the smaller and less efficient power plants that have been closed in China would have likely been greater than the reported data for some developed countries. According to SERC (2008b), the average unit capacity of the small thermal units that were closed was $26 \mathrm{MW}$ and the average operating life was 27 years. It was assumed that the emission factor for closed small units was similar to the emission factor for small and medium-sized industrial combustion facilities provided by the EU. A mean emission factor of $1 \mu \mathrm{g}$ I-TEQ ton $^{-1}$ is used in this study.

The annual power production was calculated from the average annual operation of $5221 \mathrm{~h}$ in 2006 and the closed installed capacity. The standard coal consumption rate for electricity supply was 440 gce $\mathrm{kWh}^{-1}$ for units with capacities less than $100 \mathrm{MW}$ (Zhao et al., 2008). The total reduction in coal consumption was calculated based on the estimated power production and coal consumption per $\mathrm{kWh}$. The emission factor was then used to estimate the reduction in emissions of $\mathrm{PCDD} / \mathrm{F}$ to air that would 
Table 2

Reduction of PCDD/F emissions to air in the power industry.

\begin{tabular}{lllll}
\hline Year & $\begin{array}{l}\text { Closed } \\
\text { installed } \\
\text { capacity } \\
\text { (MW) }\end{array}$ & $\begin{array}{l}\text { Closed } \\
\text { power } \\
\text { production } \\
\text { (billion kWh) }\end{array}$ & $\begin{array}{l}\text { Reduced coal } \\
\text { consumption } \\
\text { (thousand } \\
\text { tons) }\end{array}$ & $\begin{array}{l}\text { Reduced } \\
\text { PCDD/Fs } \\
\text { (g I-TEQ) }\end{array}$ \\
\hline 2006 & 3140 & 16 & 7040 & 7 \\
2007 & 14,380 & 75 & 33,000 & 33 \\
2008 & 16,690 & 87 & 38,280 & 38 \\
Total & 34,210 & 178 & 78,320 & 78 \\
\hline
\end{tabular}

have been realized due to the closure of the smaller power plants (see Table 2). It was estimated that the closures of the smaller, less efficient power plants over the past 3 years has reduced the emissions of PCDD/Fs by $78 \mathrm{~g} \mathrm{I-TEQ.} \mathrm{If} \mathrm{the} \mathrm{closure} \mathrm{target} \mathrm{of} 50 \mathrm{GW}$ of small thermal power units is achieved during the 11th FiveYear Plan period, the total reduction of PCDD/F emissions to air would be $115 \mathrm{~g}$ I-TEQ.

\section{Cement industry}

\subsection{Recent developments, energy consumption and pollutant emissions in China's cement industry}

China is the world's largest producer of cement. In 2007, 1.35 billion tons, approximately half of the total global output, was produced. The average annual output of the Chinese cement industry increased at an annual rate of as much as $12.55 \%$ during the period of the 10th Five-Year Plan (2001-2005) compared to the rate of $4.51 \%$ during the 9th Five-Year Plan (1996-2000) (China Cement Association, 2007-2008).

Cement production is an energy-intensive process, mainly because of the fuel requirements of kilns. Energy accounts for 20$40 \%$ of the total manufacturing cost of cement. In 2006, the Chinese cement industry consumed 131 million tons of standard coal, equal to 163 million tons of common coal. This amounts to $6.8 \%$ of the total consumption of coal in that year. The electricity consumption by the cement industry was 104.3 billion kWh, amounting to approximately of $3.7 \%$ the electricity consumption in the whole country (Zhou, 2007a).

Due to the prevalence of small-scale production plants and low-efficiency technology such as vertical shaft kilns, China's cement industry was $8 \%$ more carbon-intensive than the global average (Worrell et al., 2001). $\mathrm{CO}_{2}$ emissions in the cement industry were approximately 867 million tons, which contributed $22.8 \%$ of Chinese $\mathrm{CO}_{2}$ emissions in 2005 (Wang, 2006).

\subsection{Upgrade new drying process kilns and phase out vertical shaft kilns}

Efforts to increase energy efficiency in the cement industry are based primarily on application of a new dry process and elimination of vertical shaft kilns. Compared with the new dry process, vertical shaft kilns have a small capacity and are considered an obsolete technology. They were rarely used in developed countries, but had dominated China's cement production for a long time (Karstensen, 2006a). In 2005, the proportion of vertical shaft kilns and small dry-process hollow kilns still accounted for $55 \%$ of total cement production (NDRC, 2006d). Vertical shaft kilns usually produce less than 300 tons of clinker per day and consume from $14 \%$ to $105 \%$ more coal per ton of clinker (Karstensen, 2006a). Air pollution control devices commonly used by vertical shaft kilns are wet-membrane dust collection equipment, which has low efficiency and is difficult to recover the dust back to the production.

In 2006, the Chinese government set a series of policies promoting the adjustment of the cement industry. First, eight national ministries or commissions jointly issued the notice on issuance of several opinions on accelerating cement industrial restructuring on April 13, 2006 (NDRC et al., 2006b). NDRC further launched the Cement Industry Development Policies and the Special Plan for the Development of the Cement Industry to bring forward guidelines and objectives for optimization and restructuring of the cement industry (NDRC, 2006a; NDRC, 2006d). It was hoped that by the year 2010 , the proportion of new dry process in cement production would reach the goal of $70 \%$. The number of enterprises is expected to decrease from more than 5000 to 3500 , with average annual output rising from 200 thousand tons to 400 thousand tons; the annual production capacity of the top 10 cement enterprises should be at or above 30 million tons; the energy intensity of the new dry process will be reduced from $130 \mathrm{~kg}$ standard coal per ton clinker to $110 \mathrm{~kg}$ standard coal per ton clinker and the integrated energy consumption per unit of product will decrease by $25 \%$. Furthermore, 250 million tons of outdated and obsolete cement production capacity will be eliminated during the 11 th Five-Year Plan period.

To achieve these goals and promote the structural shift of the cement industry, China has selected 60 large enterprises for preferential development. These enterprises will enjoy government support in developing new projects, merger and acquisition, and preferential treatment in financing and land approval (Liu (2007)). Currently, the proportion of new dry kilns rose from $14.12 \%$ in 2001 to $61.82 \%$ in 2008 (Digital Cement China Cement Association, 2009). In addition, NDRC developed a quantified closure capacity for each province, with an overall target of closing 136 million tons of outdated cement production capacity between 2007 and 2008, and 148 million tons between 2009 and 2010 (NDRC, 2007e). Furthermore, NDRC promulgated a formal announcement of list of obsolete cement production facilities to be closed in 2007. A total of 1474 cement production lines from 1066 enterprises with a capacity of 50 million tons were requested to be closed (NDRC, 2007b). The list of cement enterprises for closure in 2008 included 946 cement production lines from 683 enterprises (MIIT, 2008a). The majority of the production lines on the list were mechanical vertical shaft kilns, but also included a few ordinary vertical shaft kiln, wet process kilns and small dry-process hollow kilns.

In fact, the reported data showed that a total of 52 million tons of cement production capacity was eliminated in 2007, which exceeded the target number of closures (MEP, 2008).

\subsection{Reduction of $P C D D / F$ emissions to air in the cement industry}

Comprehensive data on PCDD/F emissions from the cement industry were given by Karstensen (2006b) and Karstense (2008). More than 2000 PCDD/PCDF cement kiln measurements were presented. These data indicated that the main parameters affecting formation of PCDD/PCDFs seemed to be the availability of organics in the raw materials, and temperature of the air pollution control devices. The use of hazardous wastes to replace parts of the fossil fuel was not an important factor. Modern dry kilns can meet an emission level of $0.1 \mathrm{ng} \mathrm{I}^{-T E Q ~ \mathrm{Nm}^{-3}}$. An average flue gas concentration of $0.021 \mathrm{ng} \mathrm{I}-\mathrm{TEQ} \mathrm{Nm}^{-3}$ was observed in 500 recent PCDD/PCDF measurements made by the eight international cement companies was assumed to be a more reasonable estimate to modern drying kilns. However, no measurements from vertical shaft kilns could be found in the published literature. The UNEP PCDD/Fs Toolkit (UNEP, 2005) has 
assigned an emission factor of $5 \mu \mathrm{g}$ I-TEQ per ton of cement to vertical shaft kilns. This is the same emission factor applied for wet kilns with dust collectors over $300{ }^{\circ} \mathrm{C}$, whereas an emission factor of $0.05 \mu \mathrm{g}$ I-TEQ per ton of cement is applied to all dry kilns and wet kilns where dust collector temperature is held below $200{ }^{\circ} \mathrm{C}$.

Based on emission factors, in China the increasing use of new dry process kilns instead of the decrease in vertical shaft kilns can reduce $\mathrm{PCDD} / \mathrm{F}$ emissions. The new dry process kilns have a large capacity, so a stable process, operating close to the parameter set points, is beneficial to control PCDD/F emissions (UNEP Chemicals (2006)).

The reduction of $\mathrm{PCDD} / \mathrm{F}$ emissions from the cement industry was estimated using an emission factor of $5 \mu \mathrm{g}$ I-TEQ per ton of cement and taking into consideration that the majority of closed cement kilns are vertical shaft kilns. Elimination of 52 million tons of cement capacity was estimated to have reduced PCDD/F emissions to air in 2007 by $260 \mathrm{~g}$ I-TEQ. Based on the closed production of 136 million tons between 2007 and 2008, and 148 million tons between 2009 and 2010, if the targets of closing down small cement enterprises are achieved, the total reduction PCDD/F emissions to air would have been 680 and $740 \mathrm{~g}$ I-TEQ, respectively.

\section{Iron and steel industry}

\subsection{Recent developments, energy consumption and pollutant emissions in China's iron and steel industry}

China has been the largest iron and steel producer in the world since 1996. In 2007, its total pig iron output and crude steel output rose to 469.4 and 489.2 million tons, which accounted for $49.5 \%$ and $36.4 \%$ of the world total, respectively (World Steel Association, 2008). China was responsible for $78 \%$ of the increase in the world's production of steel between 2000 and 2005 (AAM, 2009).

The iron and steel industry accounts for approximately $19 \%$ of global energy use and releases approximately $25 \%$ the direct $\mathrm{CO}_{2}$ emissions from industry (OECD/IEA, 2007). The iron and steel sector is the largest industrial consumer of energy, accounting for approximately $15 \%$ of China's total energy consumption. Although current efficiencies are much better than they were in the past decades (Guo and Fu, 2009; IEA, 2007), the average energy consumption per unit of steel is about $20 \%$ greater than that of other advanced countries (Guo and $\mathrm{Fu}, 2009$ ). The pollution caused by the iron and steel industry is also serious. While the added value of the iron and steel industrial sector is about 3.14\% of the country's GDP, the emissions of wastewater, $\mathrm{PM}$ and $\mathrm{SO}_{2}$ account for approximately $10 \%, 15 \%$ and $10 \%$, respectively, of the country's total industrial emissions (Zhou, 2007b). On a per ton of steel basis, the Chinese steel industry releases about 20 -fold more $\mathrm{PM}$ and between 3- and 5-fold more $\mathrm{NO}_{x}$ and $\mathrm{SO}_{2}$ than does the steel industry in the USA (AAM, 2009).

In China, poor energy efficiency and serious pollution from the iron and steel industry are mainly due to the fact that much of the production is at small-scale facilities (Guo and Fu, 2009; AAM, 2009; Zhu, 2008). Therefore, the government developed an aggressive strategy to eliminate small and inefficient furnaces.

\subsection{Eliminate small-scale iron and steel making furnaces}

Efforts to eliminate the small-scale facilities during the 11th Five-Year Plan began with the release of the notice on controlling the total output, eliminating the backward capacity and accel- erating the structural adjustment in iron and steel industry by eight national ministries or commissions (NDRC et al., 2006a). The Government target in the notice was to close blast furnaces with a capacity of less than $100 \mathrm{~m}^{3}$ by 2007 and those with capacities of less than $300 \mathrm{~m}^{3}$ by 2010. Steel making furnaces with less than 20 ton capacity including converters and electric arc furnaces (EAFs) were to be closed in 2007. Afterward, in April 2007, NDRC signed obligation contracts for cutting iron and steel smelting capacity with 10 provinces, autonomous regions and municipalities, including Beijing, Hebei, Shanxi, Henan, Jiangsu, Shandong, Zhejiang, Jiangxi and Xinjiang, where the outdated iron and steel production capacities were mostly concentrated. In December of the same year, NDRC signed the second set of obligation contracts with Baosteel Co. Ltd., and other 18 provinces, autonomous regions and municipalities to eliminate outdated iron and steel smelting facilities. The contract for each province listed the name of enterprises, capacities and the deadlines for closure. Capacities to be closed in the two sets of contracts (NDRC, 2007a) are given in Table 3. The total capacity of 91.92 million tons of outdated iron production would be closed, and 81.27 million tons of steel production would be eliminated between 2007 and 2010 based on the data in the two batches of contracts. According to data published by the NDRC, the first batch of 10 provinces has closed backward blast furnaces with iron capacity of 29.4 million tons, and converters and EAFs with steel capacity of 15.21 million tons by the end of November, 2007. In response to the government's efforts to save energy and eliminate the less efficient and obsolete production facilities, the iron and steel industrial sector has achieved a $2.64 \%$ reduction in energy consumption and an $18.66 \%$ reduction in fresh water consumption per ton of steel in 2007 compared to the year of 2006 (The Editorial Board of China Steel Yearbook, 2008).

\subsection{Reduction of $P C D D / F$ emissions to air in the iron and steel industry}

The iron and steel industry has been identified as a significant emitter of PCDD/Fs. The main operational units for production of iron and steel include sintering, blast furnaces, converters and EAFs. Among these, iron ore sintering and EAFs used for steel production from scrap have been reported to be the major contributors of $\mathrm{PCDD} / \mathrm{Fs}$ to air (Anderson and Fisher, 2002; European Commission, 2001; Hartenstein, 2003; Lahl, 1993; UNEP Chemicals (2006)). In the UK, $15 \%$ of the total PCDD/F emissions were from the iron and steel industry (NAEI, 2008). In China, releases during iron and steel production and sintering were one of the largest industrial sources of PCDD/Fs, and accounted for $57 \%$ of the metallurgical industry (China, 2007). It was estimated that in 2005, sinter plants would constitute the most important industrial single source of $\mathrm{PCDD} / \mathrm{Fs}$ in Europe (Quaß et al., 2004). A detailed review of PCDD/F emissions from sintering and EAF has been compiled (USEPA, 2006; UNEP, 2005). Because of differences in input materials, operational parameters and air control devices, sintering process was assigned PCDD/F emission factors to air that ranged from $20 \mu \mathrm{g}$ I-TEQ per ton sinter produced to $0.3 \mu \mathrm{g}$ I-TEQ per ton by UNEP (2005). Furthermore, UNEP (2005) recommended an emission factor of $10 \mu \mathrm{g}$ I-TEQ per ton of liquid steel. This factor was used for EAFs using dirty scrap and scrap preheating with poor controls. Emissions from EAFs using clean scrap with afterburner and fabric filter were assigned an emission factor of $3 \mu \mathrm{g}$ I-TEQ per ton of liquid steel. Where controls are placed on scrap to exclude cutting oils, and gas cleaning and fabric filters are used, emissions less than $0.1 \mu \mathrm{g} \mathrm{I}-$ TEQ per ton of liquid steel can be achieved. Compared with 
Table 3

Capacities of outdated facilities to be closed in the iron and steel industry.

(Source: NDRC, 2007a; adapted and calculated the national capacities by the authors).

\begin{tabular}{|c|c|c|c|}
\hline Contracts & Blast furnace capacities (million tons) & Converters capacities (million tons) & EAF capacities (million tons) \\
\hline \multicolumn{4}{|l|}{ First contracts } \\
\hline Capacities to be closed in 2007 & 22.55 & 11.81 & 12.42 \\
\hline Capacities to be closed between 2007 and 2010 & 39.86 & 28.25 & 13.42 \\
\hline \multicolumn{4}{|l|}{ Second contracts } \\
\hline Capacities to be closed in 2007 & 14.01 & 1.35 & 12.54 \\
\hline Capacities to be closed between 2007 and 2010 & 52.06 & 17.11 & 22.49 \\
\hline Total & 91.92 & 45.36 & 35.91 \\
\hline
\end{tabular}

Table 4

Reduction of PCDD/F emissions in the iron and steel industry.

\begin{tabular}{llll}
\hline $\begin{array}{l}\text { Type of } \\
\text { activity }\end{array}$ & $\begin{array}{l}\text { Capacity to be } \\
\text { closed (million } \\
\text { tons) }\end{array}$ & $\begin{array}{l}\text { PCDD/F emission } \\
\text { factor }(\mu \mathrm{g} \text { I-TEQ } \\
\text { per ton of } \\
\text { product) }\end{array}$ & $\begin{array}{l}\text { Estimated } \\
\text { reduced PCDD/ } \\
\text { F emissions } \\
\text { (g I-TEQ) }\end{array}$ \\
\hline $\begin{array}{l}\text { Year of 2007 } \\
\text { Blast }\end{array}$ & 36.56 & 0.01 & 0.4 \\
$\quad \begin{array}{l}\text { furnaces } \\
\text { Converters }\end{array}$ & 13.16 & 0.1 & 1.3 \\
$\begin{array}{l}\text { EAFs } \\
\text { Total }\end{array}$ & 24.96 & 3 & 74.9 \\
$\begin{array}{l}\text { Year of 2007-2010 } \\
\text { Blast } \\
\text { furnaces }\end{array}$ & 91.92 & & 76.6 \\
Converters & 45.36 & 0.01 & 0.9 \\
$\begin{array}{l}\text { EAFs } \\
\text { Total }\end{array}$ & 35.91 & 0.1 & 4.5 \\
\hline
\end{tabular}

sintering process and EAFs, blast furnaces and converters release less PCDD/Fs, with emission factors of less than $0.1 \mathrm{ng} \mathrm{TEQ} / \mathrm{Nm}^{3}$ (UNEP, 2005; Grochowalski et al., 2007). In 2004, when China submitted its National Implementation Plan (NIP) of the Stockholm Convention, emission factors of 3, 0.1 and $0.01 \mu \mathrm{g}$ I-TEQ per ton based on the UNEP PCDD/Fs Toolkit were used to estimate $\mathrm{PCDD} / \mathrm{F}$ releases to air for EAFs, converters and blast furnaces, respectively (China, 2007).

Currently, there is still no monitoring and research data of PCDD/Fs for China's small-sized iron and steel facilities. Therefore, we used the same emission factors as those used for China's NIP to estimate the reduced PCDD/F releases to air for the processes of blast furnaces, converters and EAF. If the obligation contracts signed with NDRC are completed on schedule, the total reduction in PCDD/F emissions to air would be approximately $113.1 \mathrm{~g} \mathrm{I}$-TEQ with an approximately $76.6 \mathrm{~g}$ I-TEQ reduction in 2007 (see Table 4).

However, it is important to note that the actual reduced PCDD/ Fs may be greater than estimated amounts, since most of smallsized EAFs have poor air control devices and use dirty scrap, containing cutting oils or plastic as the input materials, which contribute significant release of PCDD/Fs to air. As a result, the actual emission factor of PCDD/Fs is likely greater than that used in the China NIP, which is the average emission for EAFs. Furthermore, with the closure of blast furnaces, NDRC required that sintering facilities integrated into the iron companies should be eliminated simultaneously. Since the data for closed sintering plants have not been published, the reduced emissions for the sintering process have not been estimated in this study. It was therefore expected that closure of sintering facilities would further reduce the emissions of PCDD/Fs.

\section{Coke industry}

\subsection{Recent developments and pollutant emissions in China's coke industry}

During the 9th Five-Year Plan, China's coke output remained stable, with an average annual output of 127 million tons. In 2002, coke production decreased to 116 million tons, the least in a decade. Since then, the coke industry has experienced accelerated development with output reaching 336 million tons in 2007. This accounted for $60 \%$ of global production (The Editorial Board of China Steel Yearbook, 2008).

Metallurgical coke and foundry coke are two major coke products. Metallurgical coke is used in making iron and steel, primarily in blast furnaces to reduce iron ore to metallic iron, and foundry coke is used by foundries in furnaces for melting metal and in the preparation of molds. In 2007, $90 \%$ of coke production was consumed by the iron and steel industry (The Editorial Board of China Steel Yearbook, 2008).

In more industrially developed countries, normally $95 \%$ of coke plants are co-located with iron and steel production facilities. By contrast, in China, only $33 \%$ of coke is produced at integrated iron and steel companies (NDRC, 2006b). As the dispersed small- and medium-sized coke plants have dominated the Chinese coke market for a long time, coke production is still one of the energyintensive and highly polluting industries. It has been estimated that emissions of $\mathrm{SO}_{2}$ and total suspended particle (TSP) from coke production in 2003 were 297 thousand tons and 123 thousand tons, respectively (He, 2006). This represented $1.9 \%$ and $1.5 \%$ of the China's total emissions of $\mathrm{SO}_{2}$ and TSP. Besides the pollutants mentioned above, the coking industry contributed 15$16 \%$ of the emissions of total polycyclic aromatic hydrocarbons (PAHs) in China (Xu et al., 2006b; Zhang et al., 2007). This represented the largest single industrial source of PAH emissions.

\subsection{Promote large machinery coke ovens and eliminate primitive coke ovens}

The restructuring of the coking industry began in the late 1990s. Since then, the government has issued a set of regulations that all primitive indigenous coke ovens must be closed, smallsized machinery coke ovens need to be phased out and the new coke ovens with a battery height of less than $4 \mathrm{~m}$ are prohibited. However, with the growing demand and price, the reckless development of the coking industry began in 2002. For example, in Shanxi province, where $35-40 \%$ of China's total coke was produced and $80 \%$ of China's coke exports was provided (Xu, 2006a), at the end of 2004 there were 683 coke plants either constructed or being constructed, 512 of which were not regulated and did not meet government standards and 90\% of which did not complete environmental impact assessments 
Table 5

Emissions from the different coke ovens.

(Source: Cao, 2005).

\begin{tabular}{|c|c|c|c|c|c|}
\hline Pollutants & $\begin{array}{l}\text { Clean by-product machinery } \\
\text { coke ovens }(\mathrm{kg} / \mathrm{t})\end{array}$ & $\begin{array}{l}\text { Large machinery } \\
\text { coke ovens }(\mathrm{kg} / \mathrm{t})\end{array}$ & $\begin{array}{l}\text { Small machinery } \\
\text { coke ovens }(\mathrm{kg} / \mathrm{t})\end{array}$ & $\begin{array}{l}\text { Modified indigenous } \\
\text { coke ovens }(\mathrm{kg} / \mathrm{t})\end{array}$ & $\begin{array}{l}\text { Indigenous coke } \\
\text { ovens }(\mathrm{kg} / \mathrm{t})\end{array}$ \\
\hline $\mathrm{BaP}$ & 0.00013 & 0.001 & 0.0015 & 0.0029 & 0.034 \\
\hline $\mathrm{SO}_{2}$ & 0.59 & 0.2 & 1.936 & 1.53 & 3.41 \\
\hline TSP & 0.56 & 1.84 & 4.15 & 4.53 & 6.31 \\
\hline
\end{tabular}

Table 6

Capacities of outdated facilities to be closed in the coke industry.

(Source: NDRC, 2007c; NDRC, 2007d; MIIT, 2008b).

\begin{tabular}{|c|c|c|c|c|c|c|}
\hline \multirow[t]{3}{*}{ Year } & \multicolumn{6}{|c|}{ The coke companies to be closed } \\
\hline & \multicolumn{3}{|c|}{ Coke companies using small machinery coke ovens } & \multicolumn{3}{|c|}{ Coke companies producing primitive coke, semi-coke and modified coke } \\
\hline & Number of companies & Number of coke ovens & Capacity (thousand tons) & Number of companies & Number of coke ovens & Capacity (thousand tons) \\
\hline $2007(1)$ & 69 & 99 & 10,759 & 228 & 327 & 9295 \\
\hline $2007(2)$ & 60 & 76 & 8150 & 86 & 137 & 4480 \\
\hline 2008 & 176 & 216 & 30,540 & 125 & 125 & 6379 \\
\hline
\end{tabular}

(Xu, 2006a). The pollutant emissions from these small-scale and non-compliant coke plants are notably greater than those from advanced plants. It has been reported that there were significant differences in pollutant emissions among coke ovens due to variations in technologies (see Table 5) (Cao, 2005). Considering the rapid proliferation of small coke ovens and their subsequent cause of air pollution, since 2004, the government has promulgated stricter policies for the coke industry. Nine Chinese central agencies jointly issued an urgent notice for refining and rectifying the coke industry to curb further investment and construction of the smaller less efficient facilities (NDRC et al., 2004). Subsequently, NDRC announced the admittance condition of coking industry to impose industrial location, manufacturing technology and equipment, product quality, energy consumption, pollution emission standards and cleaner production standards (NDRC, 2004). In 2005, Steel Industry Development Policies required that the coke industry upgrade technology to achieve the coke ovens with a $6 \mathrm{~m}$ carbonization chamber, use the dry coke quenching system and dust collection equipment and apply coke oven gas desulfurization systems and recover coke oven gases (NDRC, 2005). To accelerate the industrial upgrade and minimize excess production, NDRC published the notice on guiding opinions for accelerating coke industrial restructuring in 2006, which defined the further rules and goals of coke industry structure adjustment (NDRC, 2006b). Those facilities that produce primitive coke and modified coke were to be completely eliminated, and coke ovens of less than $4.3 \mathrm{~m}$ height would be phased out in 2007. However, due to economic considerations closure of coke oven in these categories in China's western region was delayed until the end of 2009.Based on the requirements of the industrial policies mentioned above, China's NDRC has twice published lists of coke companies to be closed in 2007 (NDRC, 2007c; NDRC, 2007d). MIIT announced the list of companies to be closed in 2008 (MIIT, 2008b) (see Table 6). The coke companies on the lists can be classified into two types: those of small capacity and those producing primitive coke, including primitive coke, semi-coke and modified coke. Most of the facilities to be closed were in Shanxi, Shaanxi, Inner Mongolia, Yunnan and Guizhou provinces. $42 \%$ of small machinery coke companies and $94 \%$ of closed semi-coke companies on the 2008 list were in Shanxi province and Shaanxi province. As a result, the most significant change in the production structure of the coke industry has been the rapid expansion of more modern coke facilities and the closure of obsolete and the smaller, inefficient facilities. For example, in Shanxi province the machinery coke output increased from $39 \%$ of the total coke output in 2000 to $97 \%$ of the total coke output in 2007 (Shanxi Statistical Bureau, 2008).

\subsection{Reduction of $P C D D / F$ emissions to air in the coke industry}

The release of PCDD/Fs from coke production has not been extensively studied. It is generally believed, from the limited data available, that the emission of dioxins for coke making mainly occurs during the pushing of coke, the charging of coal and the quenching of hot coke. It has been reported that emission of PCDD/Fs measured at the quenching tower in a coke plant with an annual production capacity of 670 thousand tons was $0.15 \mathrm{ng}$ ITEQ $\mathrm{Nm}^{-3}$ (Bremmer et al., 1994). An emission factor of $0.3 \mu \mathrm{g} \mathrm{I}$ TEQ ton $^{-1}$ was developed and used to estimate the dioxin releases from coke plants using technology such as afterburner and dust removal equipment in the UNEP PCDD/Fs Toolkit (UNEP, 2005). The emission factor of $3 \mu \mathrm{g}$ I-TEQ $\operatorname{ton}^{-1}$ for air has been applied to coke facilities where no dust removal device is in use (UNEP, 2005). Recently, Liu et al. (2009) identified that there was a large variance of PCDD/F emissions among three coke plants due to the differences of the coking techniques and end-of-pipe control devices used. The PCDD/Fs released in mixed emitted gases from charging of coal and the pushing of coke at a coke plant with an annual production capacity of 200 thousand tons was $1697.7 \mathrm{pg}$ WHO-TEQ $\mathrm{Nm}^{-3}$. A coke plant that produced 1770 thousand tons per year by use of the dry quenching method with recovery of heat and removal of dust by bag filters emitted only $1.2 \mathrm{pg}$ WHO-TEQ $\mathrm{Nm}^{-3}$ during coke pushing. In another coke plant with an annual production capacity of 512 thousand tons, which used bag filters to capture emissions during coal charging, the concentration of PCDD/Fs in emission gas from coal charging was 55.2 pg WHO-TEQ Nm${ }^{-3}$. As a result, estimates of coke oven emissions have an inherent uncertainty because of the limited data available and the problems associated with attempts to capture and measure the emissions.

Through analysis of the lists published by the NDRC and the MIIT, the average capacity of the small machinery coke ovens was approximately 126 thousand tons, compared to about 34 
Table 7

Reduction of PCDD/F emissions in the coke industry.

\begin{tabular}{|c|c|c|c|c|c|}
\hline \multirow[t]{2}{*}{ Year } & \multicolumn{2}{|c|}{ The machinery coke ovens to be closed } & \multicolumn{2}{|c|}{ The primitive coke ovens to be closed } & \multirow[t]{2}{*}{ Total Reduced PCDD/Fs (g I-TEQ) } \\
\hline & Capacity (thousand tons) & Reduced PCDD/Fs (g I-TEQ) & Capacity (thousand tons) & Reduced PCDD/Fs (g I-TEQ) & \\
\hline 2007 & 18,909 & 27 & 13,775 & 41 & 68 \\
\hline 2008 & 30,540 & 43 & 6379 & 19 & 62 \\
\hline Total & 49,449 & 70 & 20,154 & 60 & 130 \\
\hline
\end{tabular}

thousand tons of capacity for primitive coke ovens (including semi-coke and modified coke). Based on production capacity, the $\mathrm{PCDD} / \mathrm{F}$ emission of closed small machinery coke ovens was estimated to be similar to the value of $1697.7 \mathrm{pg}$ WHO-TEQ $\mathrm{Nm}^{-3}$ reported by Liu et al. (2009). This rate of emission is approximately equivalent to $1.42 \mu \mathrm{g}$ I-TEQ ton $^{-1}$ of coke produced. Since production capacities of primitive coke ovens are too small to afford dust removal devices, the emission factor of $3 \mu \mathrm{g} \mathrm{I-}$ TEQ ton $^{-1}$ given by UNEP PCDD/Fs Toolkit was used to estimate the emissions from primitive coke ovens that were closed. The reduction in PCDD/F emissions to air in 2007 and 2008 due to closure of these facilities would have been 68 and $62 \mathrm{~g} \mathrm{I-TEQ,} \mathrm{if}$ the plans of closure had been achieved (see Table 7).

\section{Discussions and conclusions}

China's government has made great efforts to achieve its target of energy conservation and pollution discharge reduction for the 11th Five-Year Plan. To support the elimination of inefficient, obsolete production facilities, besides published regulations mentioned above, the government strengthened the management and supervision to the outdated companies and adopted the compensation mechanism for the closure.

The supervision includes the following elements:

(1) The companies to be closed cannot enjoy preferential price policies on electricity and need to pay higher rates for electricity compared to other companies. The electricity department can cut off the supply of electricity to the companies that have not eliminated the obsolete facilities within the stipulated date.

(2) Financial institutions cannot provide new credit and should call in existing loans to companies that are required to close.

(3) The Administration of Land and Resources should strictly limit and supervise land usage and cannot provide land permits to companies that are required to close.

(4) The Administration of Industry and Commerce can suspend the operating licenses from companies that have not eliminated the backward capacities by the stipulated date.

(5) The Administration of Environmental Protection can suspend the pollutant discharging licenses from the companies that have not eliminated the backward capacities within the stipulated date.

(6) If the local government cannot complete the closure target allocated by the central government, new industrial projects are not allowed in these regions.

(7) To enhance public participation and strengthen supervision of the whole society, the government posted the lists of the obsolete facilities to be closed and the closure schedule.

The Ministry of Finance has promulgated Interim Measures on the Administration of Central Government Reward for the Closure to compensate companies for the closed facilities in 2007
(Ministry of Finance, 2007). This regulation emphasized that local governments were primarily responsible for the elimination of and compensation for closure of outdated facilities. The central government established a special fund to reward companies that eliminated the outdated capacities, especially in some underdeveloped regions. Therefore, each province has developed their compensation regulations based on the different industrial sectors and different scale facilities. A list of compensations provided to companies that can eliminate obsolete and inefficient facilities on time in Shanxi province is provided (see Table 8). The central government also allocated 3.19 billion Yuan RMB to reward phasing out obsolete facilities in 2007. The rewards were increased to 4 billion Yuan RMB in 2008, which accounted for $15 \%$ of total funds on energy conservation and emission reduction. Closing outdated facilities and application of more advanced technologies, PCDD/F emissions from these key energy-intensive industrial sectors have been reduced, even though decisions regarding these measures are normally concerned with energy efficiency and normal pollutants.

For the power industry, estimated reduction of PCDD/F emissions for 2006, 2007 and 2008 was 7, 33 and $38 \mathrm{~g} \mathrm{I-TEQ,}$ respectively. The total reduction of PCDD/Fs to air, during the 11th Five-Year Plan, is estimated to be $115 \mathrm{~g}$ I-TEQ. Since the cement industry was the most significant contributor to PCDD/F emissions, closure of outdated facilities was estimated to have reduced emissions of PCDD/Fs to air by $260 \mathrm{~g}$ I-TEQ in 2007. A reduction of $1420 \mathrm{~g}$ I-TEQ can be estimated between 2007 and 2010. Closures of outdated iron and steel capacities will result in a reduction of approximately $113.1 \mathrm{~g}$ I-TEQ between 2007 and 2010. Closures of obsolete, and small-scale, inefficient coke facilities was estimated to reduce emissions of PCDD/Fs by about $130 \mathrm{~g}$ I-TEQ between 2007 and 2008.

China has not established ongoing inventories of dioxin releases. There was only one inventory of estimated dioxin releases for 2004, which was made in 2007 when China submitted its NIP to the Stockholm Convention on POPs. Thus, it is difficult to present the percentage of reduced PCDD/F emissions through phasing out obsolete facilities in total dioxin emissions for each year. However, compared with the estimated PCDD/F emissions in 2004, the reduced PCDD/F emissions from the power, cement, iron and steel and coke industries through phasing out obsolete facilities in 2007 was approximately 13\%, 71\%, 51\% and 28\% of total dioxin emissions to air from the power, cement, iron and steel and coke industries, respectively. The relatively great difference in estimates by the NIP and our investigation, especially for the cement industry, was caused by the difference of a selected emission factors.

Aside from the industrial sectors mentioned above, the government has also developed a plan to reduce emissions from other energy-intensive industrial sectors, including electrolytic aluminum production, iron alloy production, calcium carbide production, paper making and so on. Considering the formation of dioxins in industrial thermal processes and chemical 
Table 8

Compensation for the closed enterprises in Shanxi province.

(Source: General Office of the People's Government of Shanxi Province, 2008).

\begin{tabular}{|c|c|}
\hline Industrial sectors & Compensation \\
\hline \multicolumn{2}{|l|}{ Power industry } \\
\hline Closed units from five largest national power generation groups & No \\
\hline $\begin{array}{l}\text { Closed units which are local state-owned enterprises or raised money from } \\
\text { enterprise employees }\end{array}$ & 200 million Yuan RMB per 10 MW units \\
\hline \multicolumn{2}{|l|}{ Cement industry } \\
\hline Vertical shaft kilns with the diameter less than $3 \mathrm{~m}$ & 0-300 thousand Yuan RMB per kiln ${ }^{a}$ \\
\hline Vertical shaft kilns with the diameter more than or equal to $3 \mathrm{~m}$ & 300 thousand Yuan RMB to 500 thousand Yuan RMB per kiln ${ }^{a}$ \\
\hline Dry-process hollow kilns & 500 thousand Yuan RMB to 1 million Yuan RMB per kiln ${ }^{a}$ \\
\hline Wet-process kiln & 1.6 million Yuan RMB to 2 million Yuan RMB per kiln \\
\hline \multicolumn{2}{|l|}{ Iron and steel industry } \\
\hline Blast furnaces below $100 \mathrm{~m}^{3}$ in inner volume or converters less than 15 tons & No \\
\hline Facilities operated more than 5 years & $\begin{array}{l}1.8 \text { million Yuan RMB for blast furnaces with the capacity between } 100 \text { and } \\
200 \mathrm{~m}^{3} 3 \text { million Yuan RMB for blast furnaces with the capacity between } 200 \\
\text { and } 300 \mathrm{~m}^{3} 500 \text { thousand Yuan RMB for converters with the capacity less than } \\
20 \text { tons }\end{array}$ \\
\hline Facilities operated more than 5 years & $\begin{array}{l}2.8 \text { million Yuan RMB for blast furnaces with the capacity between } 100 \text { and } \\
200 \mathrm{~m}^{3} 3.5 \text { million Yuan RMB for blast furnaces with the capacity between } 200 \\
\text { and } 300 \mathrm{~m}^{3} 1 \text { million Yuan RMB for converters with the capacity less than } 20 \\
\text { tons }\end{array}$ \\
\hline \multicolumn{2}{|l|}{ Coke industry } \\
\hline Coke plants & 30 Yuan RMB per ton coke capacity \\
\hline Illegal coke plants built after 2004 & No \\
\hline
\end{tabular}

a The compensation is different because of the date of elimination.

manufacture, it implies that these industrial sectors can further contribute to a reduction of PCDD/F emissions.

Although the reduced emissions of dioxins due to closure of obsolete facilities in China's four energy-intensive industrial sectors are remarkable, due to increasing production, it cannot yet be concluded that total dioxin emissions in these industries sectors are reduced. But, these improvements certainly resulted in less emission of PCDD/F than would have otherwise occurred. The increase in output in these industrial sectors has been steadily since 2007, and the increasing output in the recent years has been mainly from large-scale facilities with advanced technologies. The emission factors applied can thus vary by orders of magnitude depending on the process technology or operation. Therefore, based on the same output, large-scale facilities contributed less PCDD/F emissions than small-scale obsolete facilities. Moreover, with the improvement of end-of-pipe control devices in China's industrial sectors, total emissions of normal pollutants such as $\mathrm{SO}_{2}$ and dust have begun to decrease. In the cement industry, emissions of $\mathrm{SO}_{2}$ and dust in 2007 were 948.3 thousand tons and 4.44 million tons compared to 1.06 million tons and 5.15 million tons in 2006, respectively, even though cement output increased $10 \%$ compared to the previous year (China Cement Association, 2007-2008). These data demonstrated that the measures of energy conservation and pollution discharge reduction would limit the increase in pollutant emissions even though the industrial output increases. Therefore, at present, when the mandatory release standards and best available techniques for dioxins have not been established in most China's industrial sectors, industrial structural adjustment for energy conservation and pollution discharge reduction is an effective manner to indirectly control and reduce dioxin emissions and fulfill its obligations to the Stockholm Convention on POPs.

Finally, the limitations of this study should be noted. The rate at which obsolete facilities, such as in the power industry, are being replaced is changing rapidly. Based on current limited information, it is difficult to do a reasonable trend analysis on $\mathrm{PCDD} / \mathrm{F}$ reduction. When the data of closed obsolete facilities are reported completely after the 11 th Five-Year Plan, we hope to estimate the future potential of $\mathrm{PCDD} / \mathrm{F}$ reduction due to measures of phasing out obsolete facilities.

\section{Acknowledgements}

This study was supported by 11th Five-Year Plan of National Technology Support Program with Grant no.2008BAC32B07, the National Basic Research Program of China ("973" Research Program) with Grant no.2007CB407307, and the Knowledge Innovation Program of the Chinese Academy of Sciences with Grant no.KZCX2-YW-420-5. John Giesy's participation was supported by the Einstein Professorship Program of the Chinese Academy of Sciences.

\section{References}

AAM (Alliance for American Manufacturing), 2009. An Assessment of Environmental Regulation of the Steel Industry in China. Washington, DC.

Anderson, D.R., Fisher, R., 2002. Sources of dioxins in the United Kingdom: the stee industry and other sources. Chemosphere 46, 371-381.

Andrews-Speed, P., 2009. China's ongoing energy efficiency drive: origins progress and prospects. Energy Policy 37, 1331-1344.

Bie, R., Li, S., Wang, H., 2007. Characterization of PCDD/Fs and heavy metals from MSW incineration plant in Harbin. Waste Management 27 (12), 1860-1869.

Bremmer, H.J., Troost, L.M., Kuipers, G., Koning, Jd, Sein, A.A., 1994. Emissions of dioxins in the Netherlands. National Institute of Public Health and Environmental Protection (RIVM) and Netherlands Organization for Applied Scientific Research (TNO), Report No. 770501018

Cao, H.X., 2005. Study on the total emission of the pollutant of Shanxi's coking industry. SCI/TECH Information Development \& Economy 15 (9), 161-163 in Chinese.

China Cement Association, 2007-2008. In: China Cement Almanac, 2007-2008. China Building Material Press, Beijing (in Chinese).

China Electricity Yearbook Editorial Board, 2007-2008. In: China Electricity Yearbook 2007-2008. China Electric Power Press, Beijing, China (in Chinese).

China, 2007. The People's Republic of China National Implementation Plan for the Stockholm Convention on Persistent Organic Pollutants, Beijing.

Digital Cement China Cement Association, 2009 (in Chinese). 〈http://www. dcement.com/Article/200903/72353.html >. 
European Commission, 2001. Community Strategy for dioxins, furans and polychlorinated biphenyls. Communication from the Commission to the Council, the European Parliament and the Economic and Social Committee (COM (2001) 593 final). Official Journal of the European Communities, C322/2.

Fang, J., Shang, Q., Li, Q., 2006. The analysis and suggestions on China's small coalfired plants. China Power Enterprise Management 9/10, 49-50 in Chinese.

Fernández-Martínez, G., López-Vilariño, J.M., López-Mahía, P., MuniateguiLorenzo, S., Prada-Rodríguez, D., Abad, E., Rivera, J., 2004. First assessment of dioxin emissions from coal-fired power stations in Spain. Chemosphere 57 (1), 67-71.

General Office of the People's Government of Shanxi Province, 2008. Administrative Measures on the Special Funds for the Energy Conservation of Shanxi (in Chinese). 〈http://www.shanxigov.cn/n16/n8319541/n8319612/ n8321678/n8321783/8707501.html $\rangle$.

Graus, W.H.J., Worrell, E., 2007. Effects of $\mathrm{SO}_{2}$ and $\mathrm{NO}_{x}$ control on energy-efficiency power generation. Energy Policy 35, 3898-3908.

Grochowalski, A., Lassen, C., Holtzer, M., 2007. Determination of PCDDs, PGDFs, PCBs and HCB emissions from the metallurgical sector in Poland. Environmental Science and Pollution Research 14 (5), $326-332$.

Guo, Z.C., Fu, Z.X., 2009. Current situation of energy consumption and measures taken for energy saving in the iron and steel industry in China. Energy Available online.

Hartenstein, H.U., 2003. Dioxin and furan reduction technologies for combustion and industrial thermal process facilities. In: Fiedler, H. (Ed.), The Handbook of Environmental Chemistry Vol. 3, Part 0: Persistent Organic Pollutants. Springer-Verlag, Berlin and Heidelberg.

He, Q.S., 2006. Characterization, emission factors and estimated emissions of dust and VOCs from coke production in China. PhD dissertation. Guangzhou Institute of Geochemistry, Chinese Academy of Science, Guangzhou, China (in Chinese).

IEA (International Energy Agency), 2007. World Energy Outlook 2007_China and India Insights, Paris.

Japan M.O.E. (Japan Ministry of the Environment), 2005. Dioxin Emission Inventory 2004, Tokyo

Karstensen, K.H., 2006a. Cement production in vertical shaft kilns in China-status and opportunities for improvement. Report to the United Nations Industrial Development Organization. UNIDO Contract RB-308-D40-8213110-2005, 31 January.

Karstensen, K.H., 2006b. Formation and release of POPs in the cement industry, second editor. Report to World Business Council for Sustainable Development, 30 January.

Karstensen, K.H., 2008. Formation, release and control of dioxins in cement kilns. Chemosphere 70, 543-560.

Lahl, U., 1993. Sintering plants of steel industry - the most important thermical $\mathrm{PCDD} / \mathrm{F}$ source in industrialized regions. Organohalogen Compounds 11 311-314.

Levine, M., Aden, N., 2008. Global carbon emissions in the coming decades: the case of China. Annual Review of Environment and Resources $33,19-38$.

Levine, M., Zhou, N., Price, L., 2009. The greening of the middle kingdom. The story of energy efficiency in China. The Bridge 39 (2), 44-54

Liao, H., Fan, Y., Wei, Y.M., 2007. What induced China's energy intensity to fluctuate: 1997-2006? Energy Policy 35, 4640-4649.

Lin, L.F., Lee, W.J., Li, H.W., Wang, M.S., Chang-Chien, G.P., 2007. Characterization and inventory of PCDD/F emissions from coal-fired power plants and other sources in Taiwan. Chemosphere 68, 1642-1649.

Liu, G., Zheng, M., Ba, T., Liu, W., Guo, L., 2009. A preliminary investigation on emission of polychlorinated dibenzo-p-dioxins/dibenzofurans and dioxinlike polychlorinated biphenyls from coke plants in China. Chemosphere 75 692-695.

Liu, Z., 2007. Analysis of status of 60 cement enterprises emphatically supported by the state. Digital Cement China Cement Association (in Chinese). 〈http:// www.dcement.com/Article/200704/42285.html >.

Lu, Y.L., Giesy, J.P., 2005. Science-based decision-making to reduce risks from persistent organic pollutants (POPs). Chemosphere 60, 729-730.

McKay, G., 2002. Dioxin characterisation, formation and minimisation during municipal solid waste (MSW) incineration: review. Chemical Engineering Journal 86, 343-368.

MEP (Ministry of Environment Protection), 2008. The 2007 Report on the State of the Environment in China. Beijing (in Chinese)

MIIT, 2008a. A proposed announcement of a list of backward cement enterprises to be closed in 2008 (in Chinese)

MIIT, 2008b. Announcement of the list of backward calcium carbide enterprises, calcium carbide enterprises and coke enterprises to be closed in 2007 (Ref. No. 8 Announcement of the MIIT) (in Chinese). 〈http://www.miit.gov.cn/ $\mathrm{n} 11293472 / \mathrm{n} 11295023 / \mathrm{n} 11297848 / 11721945 . \mathrm{html}\rangle$.

Ministry of Finance, 2007. Interim Measures on the Administration of Central Government Reward for the Closure (in Chinese). <http://www. mof.gov.cn/mof/zhengwuxinxi/caizhengwengao/caizhengbuwengao2008 caizhengbuwengao20081/200805/t20080519_29014.html >.

NAEI (UK's National Atmospheric Emissions Inventory), 2008. UNECE emission estimates to 2006-Dioxins, Department of Environment Food and Rural Affairs, UK.

National Energy Administraion (NEA), 2009. A news conference on "The capacities of closed small thermal units exceed the target of 11 th Five-
Year Plan". 〈http://www.china.com.cn/zhibo/2009-07/30/content_18231593. htm $>$.

NBSC (National Bureau of Statistics of China), 2001-2008. China Statistics Yearbook 2001-2008. China Statistics Press, Beijing, China (in Chinese).

NDRC, 2004. Announcement No. 76 [2004] of NDRC on the admittance conditions of the Calcium Carbide Industry, the Calcium Carbide Industry and the Coke Industry (in Chinese). <http://www.sdpc.gov.cn/zcfb/zcfbgg/zcfbgg2004/ t20050614_7486.htm>.

NDRC, 2005. Steel Industry Development Policies (Ref. No. 35 Decree of the NDRC) (in Chinese). 〈http://www.sdpc.gov.cn/zcfb/zcfbl/zcfbl2005/t20050719_ 52618.htm >.

NDRC, 2006a. Cement Industry Development Policies (Ref. No. 50 Decree of the NDRC) (in Chinese). 〈http://www.sdpc.gov.cn/zcfb/zcfbl/12006/t20061019_ 89081.htm >.

NDRC, 2006b. Notice on Guiding Opinions for Accelerating Coke Industrial Restructuring (in Chinese). <http://www.ndrc.gov.cn/zcfb/zcfbtz/tz2006/ t20060328_64517.htm >.

NDRC, 2006c. Notice on improving checking on the closure of small thermal power plants (in Chinese). 〈http://www.ndrc.gov.cn/zcfb/zcfbtz/tz2006/t20060314 62975.htm >.

NDRC, 2006d. Special Plan for the Development of the Cement Industry (in Chinese). 〈http://www.ndrc.gov.cn/zcfb/zcfbtz/tz2006/t20061019_89080. htm $>$.

NDRC, 2007a. A special column of eliminating backward production capacities (in Chinese). 〈http://gys.ndrc.gov.cn/gtttlh/〉.

NDRC, 2007b. Announcement of a list of backward cement enterprises to be closed in 2007 (Ref. No. 93 Announcement of the NDRC) (in Chinese). <http://www. sdpc.gov.cn/zcfb/zcfbgg/2007gonggao/t20080107_183637.htm $\rangle$.

NDRC, 2007c. Announcement of the first list of backward calcium carbide enterprises, calcium carbide enterprises and coke enterprises to be closed in 2007 (Ref. No. 69 Announcement of the NDRC) (in Chinese). 〈http://www. sdpc.gov.cn/zcfb/zcfbgg/2007gonggao/t20071019_165623.htm >.

NDRC, 2007d. Announcement of the second list of backward calcium carbide enterprises, calcium carbide enterprises and coke enterprises to be closed in 2007 (Ref. No. 94 Announcement of the NDRC) (in Chinese). 〈http://www. sdpc.gov.cn/zcfb/zcfbgg/2007gonggao/t20080104_183452.htm 〉.

NDRC, 2007e. Notice on improving work on eliminating backward cement production capacity (in Chinese).

NDRC, Ministry of Commerce (MC), Ministry of Land and Resources (MLR), State Environmental Protection Administration (SEPA), China Customs, General Administration of Quality Supervision, Inspection and Quarantine (GAQSIQ), China Bank Regulatory Commission, China Securities Regulatory Commission, 2006a. Notice on Controlling the Total Output, Eliminating the Backward Capacity and Accelerating the Structural Adjustment in Iron and Steel Industry (in Chinese). 〈http://www.ndrc.gov.cn/zcfb/zcfbtz/tz2006/t20060717_76529. htm $>$.

NDRC, MF, MC, MLR, State Administration for Industry \& Commerce, State of Administration of Taxation, SEPA, China Banking Regulatory Commission, SERC, 2004. An urgent Notice on Issuance of Several Opinions on Refining and Rectifying the Coke Industry (in Chinese). 〈http://www.sdpc.gov.cn/zcfb/ zcfbtz/zcfbtz2004/t20050613_7009.htm >.

NDRC, MF, MLR, Ministry of Construction, MC,The People's Bank of China, GAQSIQ SEPA, 2006b. Notice on Issuance of Several Opinions on Accelerating Cement Industrial Restructuring (in Chinese). 〈http://www.sdpc.gov.cn/zcfb/zcfbtz/ tz2006/t20060425 67426.htm>.

NDRC, NEA, MEP, SERC, 2009. Announcement No. 4 [2009] of NDRC, NEA, MEP, SERC on the Closed Small Thermal Units (in Chinese). 〈http://www.sdpc.gov. $\mathrm{cn} / \mathrm{zcfb} / \mathrm{zcfbgg} / 2009 \mathrm{gg} / \mathrm{t} 20090312$ 266179.htm $\rangle$.

Ni, Y., Zhang, H., Fan, S., Zhang, X., Zhang, Q., Chen, J., 2009. Emissions of PCDD/Fs from municipal solid waste incinerators in China. Chemosphere 75 (9), 1153-1158.

Nie, Y., 2008. Development and prospects of municipal solid waste (MSW) incineration in China. Frontiers of Environmental Science \& Engineering in China 2 (1), 1-7.

OECD/IEA (International Energy Agency), 2007. Tracking Industrial Energy Efficiency and $\mathrm{CO}_{2}$ Emissions, Paris.

Olie, K., Vermeulen, P.L., Hutzinger, O., 1977. Chlorodibenzo-p-dioxins and chlorodibenzofurans are trace components of fly ash and flue gas of some municipal incinerators in The Netherlands. Chemosphere 6 (8), 455-459.

Quass, U., Fermann, M., Bröker, G., 2000. The European Dioxin Emission Inventory Stage II. Vol. 3. Assessment of Dioxin Emissions Until 2005. North Rhine Westphalia State Environment Agency on behalf of the European Commission, Directorate General for Environment, Germany. 〈http://ec.europa.eu/environ ment/dioxin/pdf/stage2/volume_3.pdf $>$.

Quaß, Ulrich, Michael, Fermann, Gunter, Bröker, 2004. The European dioxin air emission inventory project-final results. Chemosphere 54 (9), 1319-1327.

SERC (State Electricity Regulatory Commission People's Republic of China), 2008a. Annual report on electricity regulation (2007) (in Chinese). < http://www.serc. gov.cn/zwgk/jggg/200804/W020080504372495184827.pdf $\rangle$.

SERC, 2008b. Notice of the closure for small thermal units in 2007 (in Chinese). 〈http://www.serc.gov.cn/zwgk/jggg/200808/t20080819_9917.htm 〉.

SERC, 2008c. Report on the electricity sector efficiency and emissions reductions (in Chinese). 〈http://www.serc.gov.cn/jgyj/ztbg/200804/t20080415 8883. htm $>$. 
Shanxi Statistical Bureau, 2008. Shanxi Statistical Yearbook 2008. China Statistics Press, Beijing (in Chinese)

State Council of the People's Republic of China, 2007a. A General Work Plan for Energy Conservation and Pollution Discharge Reduction (Ref. No. 15 of the State Council) (in Chinese). 〈http://www.gov.cn/zwgk/2007-06/03/content 634545.htm >.

State Council of the People's Republic of China, 2007b. Notice of the state council approving the several suggestions on accelerating the shutdown of small-scale coal-fired power generating sets by NDRC (Ref. No.2 of State Council) (in Chinese). 〈http://www.gov.cn/zwgk/2007-01/26/content_509911. htm $>$.

The Editorial Board of China Steel Yearbook, 2008. China Steel Yearbook 2008. China Iron \& Steel Association. Beijing, China (in Chinese)

Tuppurainen, K., Halonen, I., Ruokojarvi, P., Tarhanen, J., Ruuskanen, J., 1998. Formation of PCDDs and PCDFs in municipal waste incineration and its inhibition mechanisms: a review. Chemosphere 36, 1493-1511.

UK DEFRA (United Kingdom of Great Britain and Northern Ireland Department for Environment Food and Rural Affairs), 2007. National implementation plan for the Stockholm Convention on Persistent Organic Pollutants.

UNEP, 2005. Standardized Toolkit for Identification and Quantification of Dioxin and Furan Releases, second ed., February 2005. UNEP Chemicals, Geneva, Switzerland.

UNEP Chemicals, 2006. Guidelines on best available techniques and provisional guidance on best environmental practices relevant to Article 5 and Annex $\mathrm{C}$ of the Stockholm Convention on Persistent Organic Pollutants.

USEPA (United States Environmental Protection Agency), 2006. An inventory of sources and environmental releases of dioxin-like compounds in the United States for the years 1987, 1995, and 2000, 2006. EPA/600/P-03/002F. Washington, DC: National Center for Environmental Assessment Office of Research and Development.
Wang, L., 2006. $\mathrm{CO}_{2}$ emission reduction with cement industry in China. China Cement 4, 34-36 in Chinese.

World Steel Association, 2008. World Steel in Figures 2008, second ed. 〈http:// www.worldsteel.org/index.php?action=publicationdetail\&id=75 $>$.

Worrell, E., Price, L., Martin, N., Hendriks, C., Meida, L.O., 2001. Carbon dioxide emission from the global cement industry. Annual Review of Energy and Environment 26, 303-329.

Xu, H.Q., 2006a. In: Development Report on China's Energy and Environment China Environmental Science Press, Beijing in Chinese.

Xu, S.S., Liu, W.X., Tao, S., 2006b. Emission of polycyclic aromatic hydrocarbons in China. Environmental Science \& Technology 40, 702-708.

$\mathrm{Xu}$, Y., Williams, R.H., Socolow, R.H., 2009. China's rapid deployment of $\mathrm{SO}_{2}$ scrubbers. Energy \& Environmental Science 2, 459-465.

Yan, J.H., Chen, T., Li, X.D., Zhang, J., Lu, S.Y., Ni, M.J., Cen, K.F., 2006. Evaluation of PCDD/Fs emission from fluidized bed incinerators co-firing MSW with coal in China. Journal of Hazardous Materials 135 (1-3), 47-51.

Zhang, Y., Tao, S., Cao, J., Coveney, R.M., 2007. Emission of polycyclic aromatic hydrocarbons in China by county. Environmental Science \& Technology 41 (3), 683-687.

Zhao, Y., Wang, S., Duan, L., Lei, Y., Cao, P., Hao, J., 2008. Primary air pollutant emissions of coal-fired power plants in China: current status and future prediction. Atmospheric Environment 42 (36), 8442-8452.

Zheng, M.H., Bao, Z.C., Zhang, B., Xu, X.B., 2001. Polychlorinated dibenzo-p-dioxins and dibenzofurans in paper making from a pulp mill in China. Chemosphere 44 (6), 1335-1337.

Zhou, H., 2007a. Review of cement industry energy consumption in 2006. China Cement 10, 26-29 in Chinese.

Zhou, S.X., 2007b. The iron and steel industry has a crucial place in pollution reduction. Central Government Gateway Network (in Chinese). <http://www gov.cn/wszb/zhibo55/content_599093.htm >.

Zhu, Y.P., 2008. In: Sectoral Study on the Iron and Steel Industry. Chatham House, London. 